\title{
Impact of Climate Change on Animal Health, Emerging and Re-emerging Diseases in Africa
}

\author{
Royford Magiri, Kaampwe Muzandu, George Gitau, \\ Kennedy Choongo, and Paul lji
}

\section{Contents}

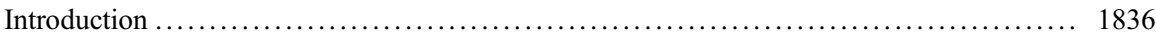

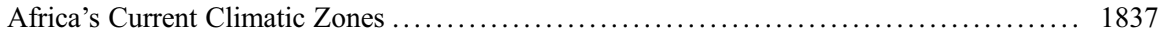

Expected Impacts of Climate Change on Livestock Production and Health .............. 1838

Vulnerability of Livestock Production Systems to Climate Change .................... 1839

Direct Effects of Climate Change on Animal Physiology: Metabolic Alterations, Suppressed

Reproduction, Oxidative Stress, Immune Suppression, Morbidity, and Mortality .......... 1839

Pathogen and Vector Ecology ............................................... 1840

Pathogen Transmission Ecology and Climate Change ............................. 1840

Vector Ecology and Climate Change ....................................... 1840

Vector-Borne Infections as Models of the Effect of Climate Change on Animal Health .... 1841

Insect-Borne Diseases .................................................... 1841

Tick-Borne Diseases .............................................. 1843

Non-Vector-Borne Diseases as Models of the Effect of Climate Change on Animal Health ... 1843

Terrestrial Non-Vector-Borne Diseases .................................... 1844

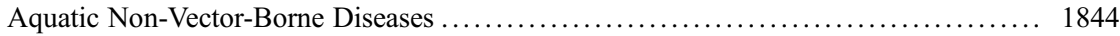

This chapter was previously published non-open access with exclusive rights reserved by the Publisher. It has been changed retrospectively to open access under a CC BY 4.0 license and the copyright holder is "The Author(s)". For further details, please see the license information at the end of the chapter.

R. Magiri $(\bowtie) \cdot$ P. Iji

Fiji National University, College of Agriculture, Fisheries and Forestry, Suva, Fiji e-mail: royford.magiri@fnu.ac.fj

K. Muzandu

School of Veterinary Medicine, University of Zambia, Lusaka, Zambia

G. Gitau

Faculty of Veterinary Medicine, University of Nairobi, Nairobi, Kenya

K. Choongo

Fiji National University, College of Agriculture, Fisheries and Forestry, Suva, Fiji

School of Veterinary Medicine, University of Zambia, Lusaka, Zambia 
Determination and Use of Meteorological, Vector and Health Data for Assessing

and Mitigating Impacts of Climate Change on Animal Health .................... 1845

Animal and Farmer Resilience and Adaptation to Effects of Climate Change on Animal

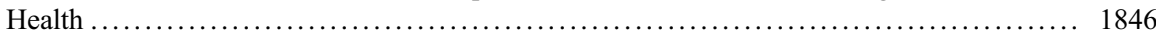

Community Resilience and Adaptation ..................................... 1846

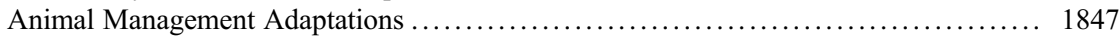

Adaptation by Strengthening Disease Prevention Practices ..................... 1848

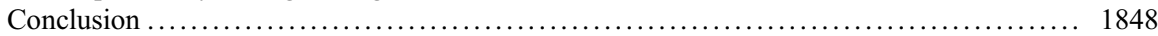

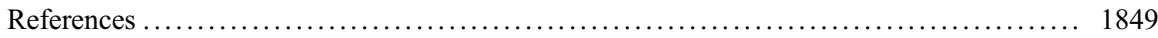

\section{Abstract}

The threat of climate change and global warming is gaining worldwide recognition. The African continent, because of its size, diversity, and its new status as a "hub" of livestock production, need to gear up to mitigate the possible impacts of climate change on animal health. The aim of this review article is to summarize the current state of knowledge regarding the influence of climate and climate change on the health of food-producing animals. Depending on its intensity and duration, heat stress may directly affect livestock health by causing metabolic disruptions, oxidative stress, and immune suppression, causing increased disease susceptibility, and death. Animal health could also be affected by emergence and re-emergence of vector- and non-vector-borne pathogens that are highly dependent on climatic conditions. The response to these challenges requires community participation in the adaptation of animal production systems to new environments and strengthening the efficiency of veterinary services delivery combined with well-coordinated public health services, since many emerging human diseases are zoonotic.

\section{Keywords}

Global warming $\cdot$ Extreme weather $\cdot$ Livestock vulnerability $\cdot$ Adaptation strategies

\section{Introduction}

Agriculture serves as the backbone of the economy of most African countries and is the largest domestic income producer. Moreover, it employs about 70-90\% of the total working population (Chauvin et al. 2012). Interestingly, this sector supplies up to $50 \%$ of household food demand in addition to their income. The livestock subsector provides over half of the value of global agricultural output and one-third in developing countries in Africa. The demand for livestock products in the developing countries is increasing with increasing human population (Steinfeld et al. 2006). However, the livestock subsector is highly susceptible to extreme climate variability. The effect of climate change is anticipated to heighten the susceptibility of livestock production systems to emerging and re-emerging diseases. Climate change is arguably the most important environmental issue currently 
affecting the livestock sector, but also ecological systems, peoples' livelihoods, and species survival (Zougmoré et al. 2016). Documented effects of climate change are: increasing number of warmer days and nights in a year; changes in rainfall pattern and volume; longer summer seasons; rising sea-levels; and increasing frequency and intensity of floods, droughts, and heat waves (Field et al. 2012; Hughes 2003). Several African governments and regional organizations are aware that increasing demand for livestock products in Africa is not matched by similar growth in local livestock production and are working towards addressing this mismatch in order to reduce dependence on imports.

Unfortunately, there is a lot of emphasis on the impact of climate change on crops in global discussions on climate with little attention paid to livestock production. There is urgent need for a paradigm shift, since it is a fact that even when there is severe crop failure, indigenous livestock have helped vulnerable communities to survive. However, the resilience of indigenous livestock is also threatened by various factors, including extreme climate variability coupled with indiscriminate cross-breeding. With climate change taking the center stage, there is merit in developing indigenous livestock due to their ability to adapt to stressful environments.

The risks associated with unmanaged livestock production in the face of climate change are causing decision-makers in Africa to raise a number of questions such as: What kind of policies would expand livestock production and give societies equal benefits? What is the best way to ensure good health for the people? What choices can ensure that livestock production is socially, biologically, economically, and climatically sustainable? Therefore, the objective of this chapter is to provide some answers to these questions by reviewing the impact of climate change on livestock production, emerging and re-emerging diseases, and adaptation strategies.

\section{Africa's Current Climatic Zones}

Climate is a long-term pattern of weather, which is the sum of sunshine, temperature, rainfall, and wind. The amount of heat from the sun plays a significant role in determining climate. The equator cuts across the center of Africa, making it the most tropical continent in the world with different regional climatic conditions (Cooper et al. 2008). The northern to north-eastern parts of the continent and the southwestern part of southern Africa have hot and dry climate with unreliable summer rainfall and arid to desert landscape (Gasse 2000). Countries along the equator experience warm and humid climate with heavy summer rainfall for most part of the year and characterized by tropical rain forests. The tropical but not equatorial regions have warm and moist climate with summer rainfall and savanna vegetation. Small areas at the northern and southern tips of Africa have Mediterranean climate, characterized by hot, dry summers and cool, wet winters.

Most of the rain in Africa occurs in the middle of the continent in the north-west to south-east direction (Fig. 1). The influence of cool-drier south-westerly prevailing 


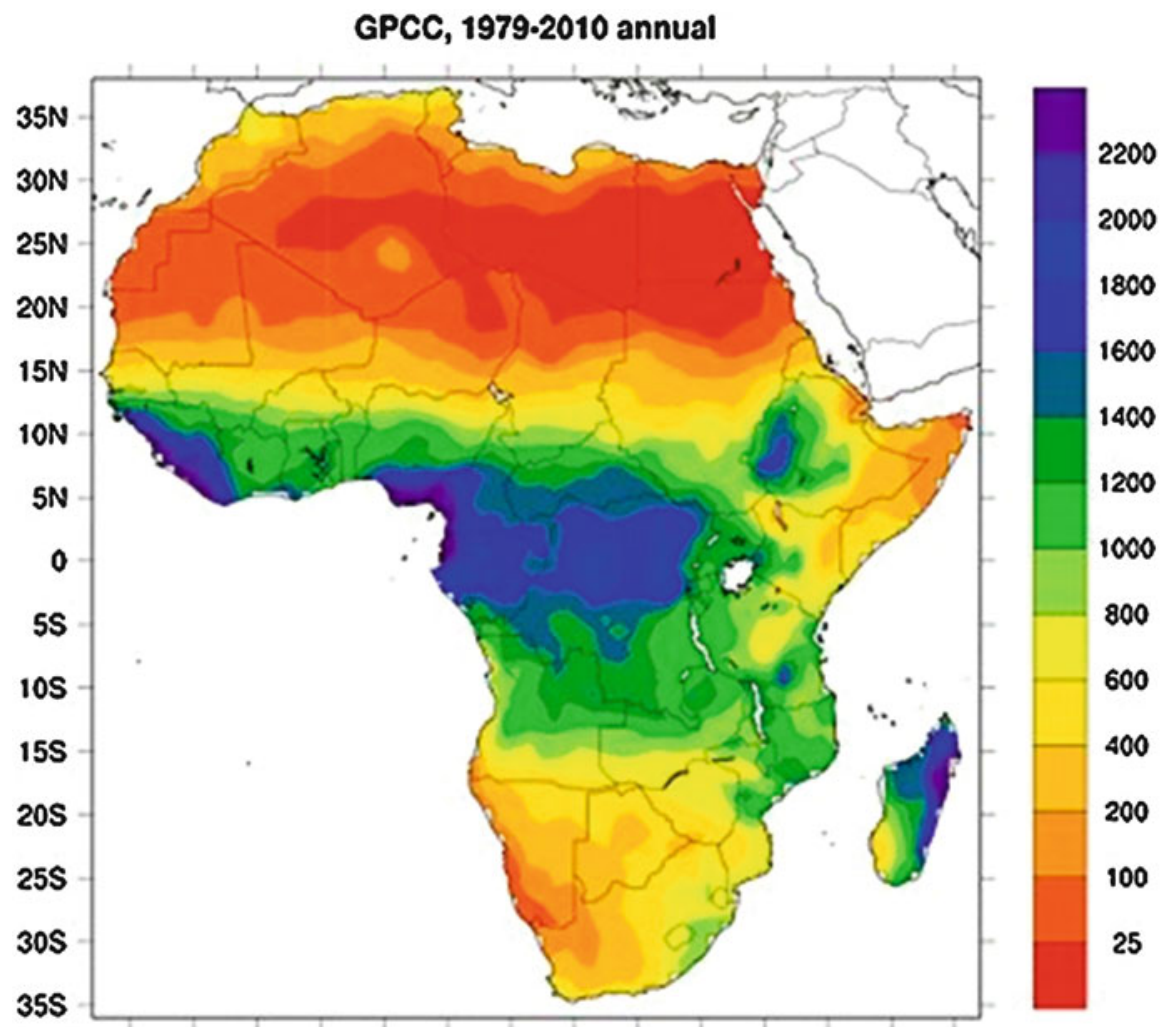

15W 10W 5W O SE IOE 15E 20E 25E 30E 35E 40E 45E SOE

Fig. 1 Map of Africa showing annual average rainfall (mm) averaged between 1979 and 2010 . (Siebert 2014)

winds reduces rainfall in the south-western part of Africa while the hot-drier northeasterly trade winds reduce rainfall in the north to north-east Africa.

\section{Expected Impacts of Climate Change on Livestock Production and Health}

Africa's contribution to global warming is low while the people living in Africa may be hit hardest by its impact. The overall impact of climate change on animal production and health is far greater than, a mere increase in average annual temperature. The effects of climate change on animal health may be direct or indirect. The direct effects are mainly due to changes in environmental conditions such as air temperature, relative humility, precipitation, drought, and floods (Lacetera 2019). These environmental conditions are responsible for temperature-related animal morbidity and mortality. Indirect effects of climate change on animal health and 
production are due to microbial density and distribution of vector-borne diseases, food and water shortages, or foodborne diseases (Lacetera 2019). The impact is characterized by: reduced feed quantity and quality; reduced feed intake; water scarcity; increased frequency and severity of diseases and deaths; poor growth rate; decreased quantity and quality of meat and milk; poor reproductive performance; increased costs for disease control and animal production (Thornton et al. 2009). All these culminate into decreased animal health and productivity, decreased animal welfare, and reduced income for affected communities and countries at large.

\section{Vulnerability of Livestock Production Systems to Climate Change}

Resilience to the impact of climate change depends on the vulnerability of affected animals and communities. Such vulnerability is the degree to which African livestock production systems are susceptible or incapable of coping with the adverse effects of climate change. In general, developing countries are more vulnerable to the impacts of climate change because they are exposed to many challenges at any time and have limited capacity to adapt. The African livestock sector is particularly vulnerable because of variability of climate, existing disease burdens, culture and economic circumstances, strong dependence on natural resources, weak infrastructure, institutional weaknesses, political and social instability (Thornton et al. 2007).

\section{Direct Effects of Climate Change on Animal Physiology: Metabolic Alterations, Suppressed Reproduction, Oxidative Stress, Immune Suppression, Morbidity, and Mortality}

New et al. (2006) analyzed the daily maximum and minimum temperatures and precipitation data from Southern and West African countries for the period 1961-2000. They found a consistent trend of increasing number of hot days and nights and decreasing extremely cold days and nights. Heat stress can occur in animals when a combination of animal and environmental factors increase body heat beyond the normal range (Young 1993). Cattle respond to acute periods of excessive heat in many ways, including decreased feed and increased water intake and increased respiratory rate (Gaughan et al. 1999). On the other hand, Beatty et al. (2006) showed that Bos taurus cattle experienced significant physiological changes while similar but less pronounced changes were experienced by Bos indicus but without a decrease in feed intake, when exposed to prolonged heat and humidity.

Heat stress due to fluctuating environmental temperatures that exceeds the thermoneutral zone for an animal is the most common stressor that can cause physiological, endocrine and immune responses that may lead to morbidity and reduced animal production (Carroll et al. 2012). Similarly, there was an increase in oxidative stress in dairy cows during the hot season (Tanaka et al. 2007). An increase in oxidative stress has been shown to increase the pathogenesis and severity of many diseases (Halliwell and Gutteridge 1990). 
Thus, direct effects of climate change on livestock physiology are observed through the increase in heat stress and have been shown to reduce resistance to diseases and reduce reproductive efficiency and productivity in general. However, heat-tolerant local animals easily adapt compared to heat-susceptible ones.

\section{Pathogen and Vector Ecology}

The life cycle of most pathogens involves a free-living stage in the environment while most vectors spend most of their time off the host and only come in contact with animals at the time of feeding.

\section{Pathogen Transmission Ecology and Climate Change}

Animal pathogens can live in the body of a host/vector or be free-living in the environment. These pathogens are more susceptible to direct effects of weather change when they are free-living in the environment. The major climate-related factors limiting pathogen survival in the environment are temperature and humidity. Climate change in Africa is causing an increase in the number of days that are hot compared to those that are cold in a year (New et al. 2006). The increasing numbers of hotter days in turn reduce humidity thereby reducing the survival of free-living pathogens in the environment. For instance, the survival of viruses during aerosol transmission or by surface contact is influenced by humidity and ambient temperature (Lowen et al. 2007). Since drought is associated with higher temperatures and low humidity and reduced availability of water, it tends to reduce the survivor and transmission of free-living pathogens into host animals.

Floods increase air humidity and create conditions favorable for survival and transmission of free-living pathogens. For example, the transmission of avian influenza viruses involves the ingestion of water containing the virus (DomanskaBlicharz et al. 2010). Similarly, helminthes and other larger parasites that have a long free-living stage thrive better during weather conditions that increase water availability (van Dijk et al. 2010). Therefore, the effects of climate change on freeliving pathogens may take different forms due to fluctuations between drought and flood years. Each pathogen in an area must be assessed on its own merit in order to have a practical adaptation strategy. Furthermore, many pathogens have short generation intervals and high rates of mutation, increasing their ability to evolve over decades and cause emerging diseases (Koelle et al. 2005).

\section{Vector Ecology and Climate Change}

In Africa, disease-transmitting vectors are equally affected by increasing number of days with hot weather and low humidity. For vectors whose life cycle involves egg, larval, nymph, and adult stages, the egg and larval stages are the most susceptible to 
changing weather patterns. It has been shown that the hatchability of Rhipicephalus decoloratus eggs reduces when temperatures are low during cold season or flood periods, while larval survival decreases when humidity is low during hot months (Leal et al. 2018). This means that warmer cold seasons and drought increase the population of these ticks and increases the risk of anaplasmosis and babesiosis, while hot seasons with low humidity decrease the population and the risk of these diseases. Similarly, higher temperatures observed during cold seasons (Elbers et al. 2015) and flooding (Ivers and Ryan 2006) may be linked to increased mosquito and Culicoides midge populations, thereby increasing the risk of diseases that they transmit such as lumpy skin Disease, Rift Valley Fever among others.

\section{Vector-Borne Infections as Models of the Effect of Climate Change on Animal Health}

There is ample literature on the effects of climate change and the epidemiology of several vector-borne species on animal and human diseases. Vector-borne animal diseases in Africa fall into two main categories: (1) Insect-borne diseases spread by mosquitoes, midges, biting flies, and Tsetse fly which transmit diseases such as Trypanosomiasis and Rift Valley Fever; (2) tick-borne diseases such as East Coast Fever (Bengis et al. 2002).

The mechanisms involved in the emergence of such diseases relating to climate are complex. Vector-borne diseases are usually transmitted by interaction between the hosts and the infected vectors. Infection prevalence is dependent on the interrelationship between hosts, pathogens, and vectors. Any climate-related factor affecting this triangular relationship will affect the vector-transmitted disease epidemiology. In this respect, the survival of the vector, its replication, distribution, density, the vector biting rate, and the pathogen's incubation rate within the vector are of particular importance.

A rise in temperature can allow some vector-borne illnesses to spread in areas with adequate rainfall. Indeed, in the absence of effective veterinary services, the spread of vector-borne diseases is largely determined by a natural boundary where environmental or climatic conditions limit the distribution of the vector and, therefore, the pathogen. Small changes in climatic conditions can have significant repercussions for disease transmission at the fringes of this natural distribution and interfere with endemic stability.

\section{Insect-Borne Diseases}

These include (a) arboviral diseases, for example, Rift Valley Fever, Lumpy Skin Disease and African Horse Sickness (b) protozoa diseases, for example, Trypanosomiasis. In the following sections, we will provide evidence, linking climate change to the spread of these diseases. 


\section{Mosquito-Borne Diseases}

Rift Valley Fever (RVF) is a significant arboviral disease already linked to climate change. It is a peracute or acute zoonotic disease, but affecting mainly domestic ruminants in Africa and transmitted by the mosquito (Mellor and Leake 2000). It is most serious in sheep and goats, resulting in death in newborn animals and abortion in pregnant animals. Epidemics associated with heavy rainfall at irregular intervals of 515 years tend to occur in eastern and southern Africa but some outbreaks in Sudan, Egypt, Senegal, and Mauritania are not related to any change in rainfall pattern. Heavy rainfall causes flooding of often dry areas and contributes to the hatching of dormant, drought-resistant, infected Aedes mosquito eggs responsible for the maintenance of the infection in dambos. Emerging mosquitoes infect an amplifying host that becomes a source of infection for many other mosquitoes that spread the disease rapidly.

Rift Valley fever outbursts are accompanied by unexpected heavy rains and flooding, mostly caused by El Niño. For example, the 1997-1998 and 2007 El Niño events were associated with very heavy rainfall in north-eastern Kenya and southern Somalia, resulting in a significant outbreak of RVF (Sang et al. 2010). Rift Valley Fever outbreaks in North and West Africa are not associated with heavy rainfall but with large rivers and dams providing ideal breeding grounds for mosquito vectors. In these areas, increasing the water storage ability for agricultural development and irrigation, in response to the drying climate, is likely to provide new suitable breeding sites for mosquitoes and may make these areas more vulnerable to RVF epidemics. In addition, RVF may become prevalent in areas where the disease has not been previously reported. Wessel born disease (WSL) is another mosquito-borne viral disease of cows, sheep, and goats that largely depends on floodwater breeding Aedes mosquitoes, and has very close epidemiological characteristics to RVF. Lumpy skin disease is a cattle disease of economic importance in Africa, causing severe losses such as damage to hides, mortality, and losses in productivity and reproduction (Krauer et al. 2016).

\section{Midge-Borne Diseases}

Wet conditions also promote the breeding of biting flies (e.g., Culicoides (Midges), Stomoxys and Tabanus spp.). African horse sickness (AHS) and bluetongue (BT) viruses are triggered by Culicoides biting midges. Therefore, the dissemination of both diseases is greatly affected by the availability of favorable conditions for breeding of midges. Blue Tongue disease was originally restricted to a belt between $40^{\circ} \mathrm{N}$ and $35^{\circ} \mathrm{S}$ worldwide. Its spread to other parts of the world has been attributed to climate change. Some major AHS outbreaks in South Africa have been linked to the combination of drought and heavy rainfall caused by El Niño-Southern Oscillation's (ENSO) warm phase. Many global climate models predict that, in the future, ENSO will occur more often.

\section{Tsetse Fly-Transmitted Diseases}

The direct and indirect effects of climate change on tsetse fly distribution and abundance would help to determine the possible spread and prevalence of trypanosomiasis in livestock (Bett et al. 2017). However, a recent study forecasting the 
expected impact of climate change on the distribution of tsetse flies suggests that the impact of climate change on population results is minimal in comparison with the consequences of population growth and the concomitant shifts in land use and tsetse natural habitat. The biggest shifts in tsetse fly distribution are predicted in the drier areas of western, eastern, and southern Africa (McDermott et al. 2002). Climate change will have less impact on tsetse fly distribution in the tropical regions of Africa. Nevertheless, the potential consequences of increased temperatures and habitat suitability changes on the vector capability of tsetse flies are not clear, and further research is needed.

\section{Tick-Borne Diseases}

Diseases which are caused by tick-transmitted pathogens in Africa include: (a) protozoal diseases (Theileriosis and Babesiosis), (b) ricketssial diseases (Anaplasmosis and Heartwater disease), and (c) viral diseases (African Swine fever).

Ticks spend a significant portion of their lives feeding off their host(s) and are therefore prone to atmospheric temperature and humidity. The climate and vegetation influence the environment and determine the distribution and abundance of ticks. Rising temperature, as a result of climate change can shorten their life cycle yet increase their reproductive rate (Estrada-Peña et al. 2012). Rather high temperatures are likely to reduce their longevity, and under drier conditions, mortality may increase. A model developed for the brown-ear tick Rhipicephalus appendiculatus, the main vector of East Coast fever (ECF), forecasts that ideal environments for the tick will have vanished in most of the southeastern portion of its distribution by the 2050s. Conversely, in western and central parts of southern Africa, more ideal places for tick survival could appear. A strong correlation between El Niño occurrences and an enhanced ECF seroprevalence has been identified in southern Zambia as a result of the increased tick vector survival (Fandamu et al. 2005). Consequently, temperature strongly affects the nature of the tick population and the diseases they spread by influencing tick distribution and seasonal incidence. Regulation of the big tick-borne diseases in large areas of Africa should focus on preserving an endogenous stable situation.

Therefore, the growth and survival of infectious immunity in bovine with tickborne diseases is dependent on an optimum interaction between cattle, disease agents, and ticks. Disruption of this optimum relationship due to climate change and subsequent changes in the distribution and availability of certain types of ticks is likely to affect endemic stability and could trigger disease outbreaks.

\section{Non-Vector-Borne Diseases as Models of the Effect of Climate Change on Animal Health}

Non-vector-borne diseases are transmitted directly after infectious organisms from the environment enter the animal, usually through inhalation (aerosol) and/or ingestion (water or feed) or through open wounds. 


\section{Terrestrial Non-Vector-Borne Diseases}

The effect of climate change on the spread of non-vector-borne diseases and their occurrence varies greatly. Changes in environmental conditions may increase or decrease the survival of the infectious agent in the ecosystem or predispose the susceptible animals to infection, as a direct or indirect result of climate change. A changing environment can also lead to increased or decreased interaction between contaminated and vulnerable species, and therefore influence transmission. Changes in temperature and humidity may influence the spatial and temporal distribution of non-vector-borne disease pathogens that spend time outside the host (Van den Bossche and Coetzer 2008). Such infections include: anthrax and blackleg, peste des petits ruminants (PPR), and foot and mouth disease (FMD) found in wind-borne aerosols, dermatophilosis, haemorrhagic septicaemia, coccidiosis, and helminthiasis (Van den Bossche and Coetzer 2008). The increase in rainfall in some areas of Africa creates temporary water bodies or permanent water bodies for irrigation in drier areas in which the intermediate snail host of $F$. hepatica survives (Van den Bossche and Coetzer 2008). While disease spread directly between animals in close contact is less climate-related, changes in the environment resulting in the loss or sporadic availability of water resources or grazing land lead to mass migration of livestock and wildlife in pursuit of water or pasture. Such movement enhances the interaction between livestock from different areas, and between wildlife and livestock, and can contribute to pathogens being transferred. Such population gatherings, animal congregations, and exchange of water and food supplies are considered to significantly contribute to the dissemination of major transboundary African diseases such as FMD, PPR, and contagious bovine pleuropneumonia. Drought, overgrazing, and extreme environmental stress arising from climate change and/or mass migration can become significant trigger factors for soil-borne disease epidemics, such as anthrax which remains dormant and viable in the soil for several decades.

Foot rot is a flood-related bacterial condition that affects ruminant interdigital tissue. Changes in the quality of the interdigital surface, due to exposure to wet conditions during floods, provide a favorable environment for bacterial growth and foot rot (Hiko and Malicha 2016). Changes in the environment as a result of climate change will also affect the migratory paths of a large range of bird species, both within and across continents. These movement path modifications can play a role in the spread and distribution of avian influenza and West Nile virus (Altizer et al. 2011).

\section{Aquatic Non-Vector-Borne Diseases}

Epizootic Ulcerative Syndrome (EUS) is a disease characterized by red spots and ulcers on the skin and often high mortality of various fish species (Songe et al. 2011). The lesions of EUS are caused by Aphanomyces invadans, and poor water quality parameters predispose fish to EUS (Pathiratne and Jayasinghe 2001). The first outbreak of EUS in Africa was recorded in 2006 in Botswana, Namibia, and Zambia in the Chobe-Zambezi river basin (Andrew et al. 2008). This was associated with 


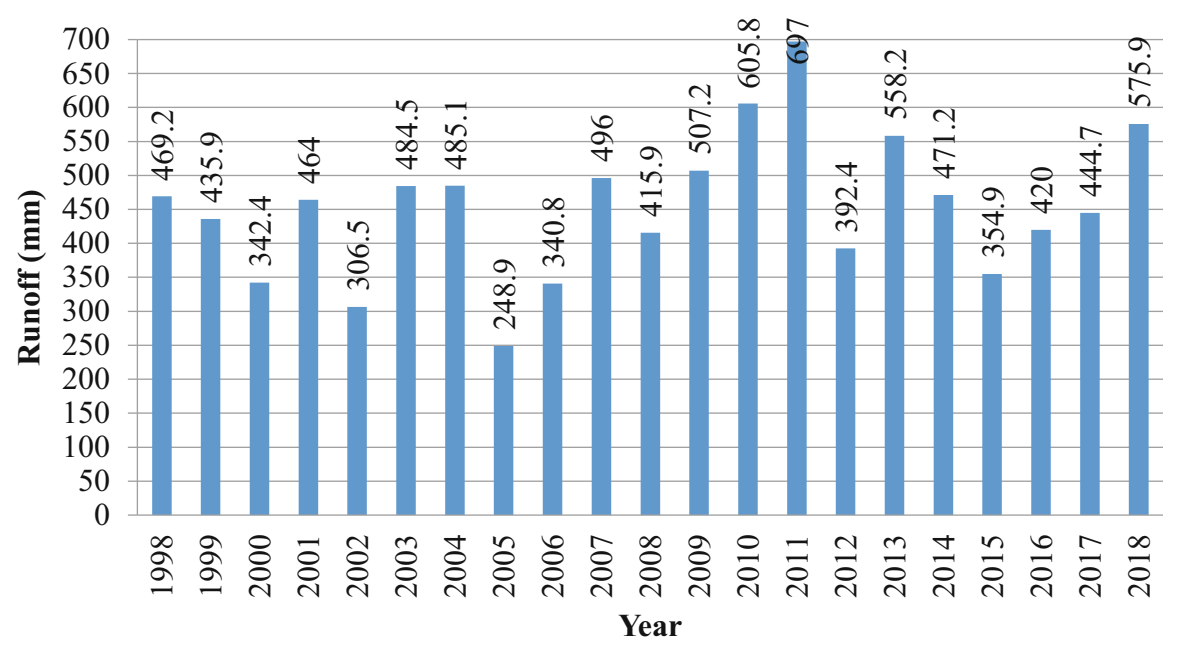

Fig. 2 Total annual water runoff on Zambezi River in Mongu, Zambia from 1998 to 2018 showing the lowest ever water runoff below $250 \mathrm{~mm}$ in 2005 due to severe drought. (Source of data, Brakenridge 2020)

river basins having thionic gleysols, soils with enough sulfur content to cause acidification of the soil upon oxidation (FAO/UNESCO 1970), and the severe drought of 2005 (Fig. 1; Brakenridge 2020) that drastically reduced the water table to expose the sulfide/sulfur horizon to air oxidation, resulting in acidic $\mathrm{pH}$ and poor water quality (Choongo et al. 2009). The high rainfall of 2006/2007 season flushed the acidic underground water to the surface, creating favorable conditions for the disease. It was observed that the disease was spreading upstream towards the underground source of the water, rather than downstream where all the dead and infected material were being washed to by the water. It is interesting to note that the water runoff on the Zambezi River has up until 2018, never reduced to the 2005 level of less than $250 \mathrm{~mm}$ and the EUS disease is so far naturally under control.

Thus, it would be important to use river water runoff data and any other meteorological data that can be used to predict future outbreaks of EUS in areas with underwater sulfur content that can be acidified when exposed to air due to lowering water table during severe drought. This would enable aquaculture farmers in such areas as the Chobe-Zambezi river basin prepare their fish ponds for sufficient alkalinization with lime in order to mitigate the possible outbreak of EUS (Fig. 2).

\section{Determination and Use of Meteorological, Vector and Health Data for Assessing and Mitigating Impacts of Climate Change on Animal Health}

The availability of reliable meteorological and disease data is necessary to design effective disease monitoring, surveillance, and early warning and response systems. The major sources of meteorological data, including temperature and precipitation, 
are obtained from ground-based and satellite measurements or interpolated gridded datasets (Heaney et al. 2016).

A web search for articles published between 1970 and 2015 on meteorology and infectious diseases in Central Africa by Heaney et al. (2016) concluded that in Central Africa, meteorological data is limited because of sparse ground-based recording stations and the lack of proper validation of available satellite data. Therefore, most studies done on the link between infectious diseases and meteorological variability may not be reliable unless infectious disease data are linked to high-quality spatially matched weather data. Spatial mismatch happens when humidity, temperature, and rainfall estimates are obtained from a place that was far from the area where disease data was collected. They advised the scientific community to be aware of the limitations of meteorological data available in Africa and ensure that there is an improvement in the quality and quantity of both meteorological and infectious disease data collected.

"Environmental change vulnerability," which includes community exposure to climatic change, its sensitivity and ability to adapt (McLeman and Hunter 2010), is considered to be very high in African countries. Thus, the need to have quality meteorological and disease data cannot be overemphasized.

\section{Animal and Farmer Resilience and Adaptation to Effects of Climate Change on Animal Health}

Coping and adapting to negative effects of climate change on animal health requires that the farming community adapts to changing circumstances, animal management systems are adapted and animal disease preventive measures are strengthened. It should no longer be business as usual.

\section{Community Resilience and Adaptation}

Most of the climate-associated emerging and re-emerging animal diseases are transmitted by agents that do not respect any boundaries and therefore, require collective stakeholder participation if effective control for improved productivity is to be achieved. In most African countries, government infrastructure meant to support farmers in livestock production and health is either very poor and unreliable or nonexistent at all. However, when assistance from government or NGOs exist, most of it focuses on the usual aspects of disease control and animal production and not really mitigating effects of climate or weather changes that increase effects of diseases on their animals. Therefore, empowering communities with knowledge and skills to adapt to climatic and weather patterns should now be a priority. Community participatory disease control and surveillance have been practiced in some areas and when supported by government projects or NGOs may yield variable results, which usually disappear when the project or support ends. This is normally the case when project activities are compromised by poor objectives and subjective practicality 
(Ayal and Muluneh 2014). In order to have really lasting benefits, there is a need to implement sustainable community based herd health programs that integrate all activities such as vaccinations, deworming, etc., into the day-to-day husbandry, with increased livestock off-take where, there is government marketing support. It has been shown that when farmer livelihood sustainability through improved income becomes the goal of their community participation, tangible results are usually obtained. The rinderpest eradication program was one such success story because livelihood sustenance was the ultimate rationale for collective community efforts (Rich et al. 2014). Therefore, resilience and adaptation to effects of climate change in Africa require that the affected communities are directly involved in adaptation strategies that are practical and centered on livelihood sustenance.

\section{Animal Management Adaptations}

Although severe droughts and floods are all considered to be a result of climate change, drought by far has the greatest impact on animal production because it drastically limits both feed and water availability. Limited feed, both in terms of quality and quantity, reduces the competence of the immune system thereby making the animals more susceptible to diseases. In most parts of Africa both feed and water are abundant during flood years. Therefore, in most cases, climate change livestock production adaptation strategies that are usually considered are those responding to the impact of drought. Floods may affect animal production more through diseases than through nutrition. Adaptation strategies can be short-term or long-term.

Unfortunately, most farmers tend to implement short-term adaptation strategies because they have immediate visible impact although they are not usually sustainable in many cases especially for large flocks or herds. Short-term strategies include increasing spending on veterinary services, destocking, trekking animal's long distances in search of water and pasture, constructing fences to protected farmland, as well as feeding through cut-and-carry and other zero-grazing practices.

Long-term resilience to effects of climate change should make management of animals according to local conditions priority number one (Nyamushamba et al. 2017). This should start by ensuring that there are a large percentage of genes from local animals in the breeding stock. Indiscriminate cross-breeding should be discouraged as it produces offspring that are not well adapted and succumb easily to any emerging diseases. Even in the midst of climate change, local breeds have traits for genetic resistance to disease and other traits for quickly adjusting to local conditions. Other management practices like feeding and housing play an important role in the maintenance of resilient, healthy, and productive animals. In fact, continuous breeding of the best performing animals under the harsh local environmental conditions is the more sustainable long-term adaptation strategy. There are many examples of resilient animal breeds that have been developed with mainly local genetics that are performing very well even in the midst of climate change. These include the Tuli and Boran cattle breeds. However, livestock farmers that have maintained their indigenous cattle breeds such as Sanga in Southern Africa (Norval et al. 1988), East 
African zebu (Scarpa et al. 2003), and the N'dama in West Africa (Mattioli et al. 2000) suffer less from the impact of environmental changes compared to those that keep breeds with a large percentage of exotic genetics.

Thus management adaptation to changing climate requires committed allocation of resources and improvements in the way land is used for livestock production, coupled with the promotion of local genetics.

\section{Adaptation by Strengthening Disease Prevention Practices}

The impact and prevalence of many diseases such as FMD, theileriosis, anaplasmosis, etc., have been increasing while the budget for controlling the diseases has been reducing in most African countries. Sufficient resources must be allocated while ensuring that the whole community is involved in improving sanitation and biosecurity. Usually disease risk factors vary with animal management systems. However, irrespective of the management system, early warning, detection, and quick response are key to preventing and controlling both emerging and re-emerging animal diseases (Black et al. 2008). Prevention and stopping the spread of diseases across an area and country should be the cornerstone of all preventive mechanisms. In addition, in order to stop the spread of high impact infectious diseases such as FMD and ASF, transboundary control measures by African countries are required. The success of the rinderpest eradication program was a result of early detection and early response globally. The world was declared to be free of rinderpest by both FAO and OIE in 2011 because of commitment to early detection and early response (Mariner et al. 2012). Unfortunately, in Africa, new diseases continue to emerge and the impact and persistence of endemic diseases is still a major challenge. In order to achieve early detection and early response, African countries must have functioning laboratories that give real time results of disease confirmation which are well coordinated with field veterinarians.

\section{Conclusion}

Climate change has certainly increased land and sea surface temperatures, leading to an increase in the number of warmer days and nights in a year. These changes have been shown to increase the severity of droughts and floods. The manner in which these climatic changes affect animal health and production has been highlighted in this review. The impact can be directly, by affecting the animal's thermoneutral zone thereby inducing stress and its subsequent effects. The effect can also be indirectly by increasing the survival of pathogens and vectors in the environment resulting in increased severity and frequency of diseases. The use of meteorological data that are spatially matched to disease data can help in achieving early warning, detection, and response to eminent diseases. In Africa, adaptation measures should include livelihood-sustenance based community participation in managing animal production according to local conditions and strengthening disease preventive practices. 


\section{References}

Altizer S, Bartel R, Han BA (2011) Animal migration and infectious disease risk. Science 331(6015):296-302

Andrew T, Huchxermeyer K, Mbeha B, Nengu S (2008) Epizootic ulcerative syndrome affecting fish in the Zambezi river system in Southern Africa. Vet Rec 163:629-632

Ayal D, Muluneh A (2014) Smallholder farmers' vulnerability to climate variability in the highland and lowland of Ethiopia: implications to adaptation strategies. Doctoral thesis, University of South Africa, Geography Department

Beatty DT, Barnes A, Taylor E, Pethick D, McCarthy M, Maloney SK (2006) Physiological responses of Bos taurus and Bos indicus cattle to prolonged, continuous heat and humidity. J Anim Sci 84(4):972-985. https://doi.org/10.2527/2006.844972x

Bengis R, Kock R, Fischer J (2002) Infectious animal diseases: the wildlife/livestock interface. Rev Sci Tech-Off Int Épizooties 21(1):53-66

Bett B, Kiunga P, Gachohi J, Sindato C, Mbotha D, Robinson T, ... Grace D (2017) Effects of climate change on the occurrence and distribution of livestock diseases. Prev Vet Med 137:119-129

Black PF, Murray JG, Nunn MJ (2008) Managing animal disease risk in Australia: the impact of climate change. Rev Sci Tech-Off Int Epizooties 27(2):563-580

Brakenridge GR (2020) Global active archive of large flood events. Dartmouth Flood Observatory, University of Colorado. https://floodobservatory.colorado.edu/SiteDisplays/278.htm. Accessed 8 Feb 2020

Carroll JA, Burdick NC, Chase CC Jr, Coleman SW, Spiers DE (2012) Influence of environmental temperature on the physiological, endocrine, and immune responses in livestock exposed to a provocative immune challenge. Domest Anim Endocrinol 43(2):146-153

Chauvin ND, Mulangu F, Porto G (2012) Food production and consumption trends in sub-Saharan Africa: prospects for the transformation of the agricultural sector. UNDP Regional Bureau for Africa, New York

Choongo K, Hang'ombe B, Samui KL, Syachaba MZ, Phiri H, Maguswi C, Muyangaali K, Bwalya G, Mataa L (2009) Environmental and climatic factors associated with epizootic ulcerative syndrome (EUS) in fish from the Zambezi Floodplains, Zambia. Bull Environ Contam Toxicol 83(4):474-478

Cooper P, Dimes J, Rao K, Shapiro B, Shiferaw B, Twomlow S (2008) Coping better with current climatic variability in the rain-fed farming systems of sub-Saharan Africa: an essential first step in adapting to future climate change? Agric Ecosyst Environ 126(1-2):24-35

Domanska-Blicharz K, Manta Z, Smietanka K, Marche S, van den Berg T (2010) H5N1 high pathogenic avian influenza virus survival in different types of water. Avian Dis 54(1 suppl): 734-737

Elbers AR, Koenraadt CJ, Meiswinkel R (2015) Mosquitoes and Culicoides biting midges: vector range and the influence of climate change. Rev Sci Tech 34(1):123-137

Estrada-Peña A, Ayllón N, De La Fuente J (2012) Impact of climate trends on tick-borne pathogen transmission. Front Physiol 3:64

Fandamu P, Duchateau L, Speybroeck N, Marcotty T, Mbao V, Mtambo J, ... Berkvens D (2005) Theileria parva seroprevalence in traditionally kept cattle in southern Zambia and El Niño. Int J Parasitol 35(4):391-396

FAO/UNESCO (1970) Key to soil units for the soil map of the world. Soil re-sources. Development and Conservation Service, FAO, Rome

Field CB, Barros V, Stocker TF, Dahe Q (2012) Managing the risks of extreme events and disasters to advance climate change adaptation: special report of the intergovernmental panel on climate change. Cambridge University Press, New York

Gasse F (2000) Hydrological changes in the African tropics since the last glacial maximum. Quat Sci Rev 19(1-5):189-211

Gaughan JB, Mader TL, Holt SM, Josey MJ, Rowan KJ (1999) Heat tolerance of Boran and Tuli crossbred steers. J Anim Sci 77:2398-2405 
Halliwell B, Gutteridge JM (1990) Role of free radicals and catalytic metal ions in human disease: an overview. Methods Enzymol 186:1-85

Heaney A, Little E, Ng S, Shaman J (2016) Meteorological variability and infectious disease in Central Africa: a review of meteorological data quality. Ann N Y Acad Sci 1382(1):31-43. https://doi.org/10.1111/nyas. 13090

Hiko A, Malicha G (2016) Climate change and animal health risk', climate change and the 2030 corporate agenda for sustainable development. Advances in sustainability and environmental justice, vol 19. Emerald Group Publishing Limited, Bingley, West Yorkshire, England, United Kingdom

Hughes L (2003) Climate change and Australia: trends, projections and impacts. Austral Ecol 28(4):423-443

Ivers CL, Ryan ET (2006) Infectious diseases of severe weather-related and flood-related natural disasters. Curr Opin Infect Dis 19:408-414

Koelle K, Pascual M, Md Yunus (2005) Pathogen adaptation to seasonal forcing and climate change. Proc Roy Soc Lond Biol Sci 272(1566):971-977

Krauer F, Riesen M, Reveiz L, Oladapo OT, Martínez-Vega R, Porgo TV, Höfliger A, Broutet NJ, Low N (2016) Zika virus infection as a cause of congenital brain abnormalities and GuillainBarré syndrome: systematic review: DATASET

Lacetera N (2019) Impact of climate change on animal health and welfare. Anim Front 9(1):26-31

Leal B, Thomas DB, Dearth RK (2018) Population dynamics of off-host Rhipicephalus (Boophilus) microplus (Acari: Ixodidae) larvae in response to habitat and seasonality in South Texas. Vet Sci 5(2):33

Lowen AC, Mubareka S, Steel J, Palese P (2007) Influenza virus transmission is dependent on relative humidity and temperature. PLoS Pathol 3(10):e151

Mariner JC, House JA, Mebus CA, Sollod AE, Chibeu D, Jones BA, Roeder PL, Admassu B, Van't Klooster GGM (2012) Rinderpest eradication: appropriate technology and social innovations. Science 337(6100):1309-1312. https://doi.org/10.1126/science.1223805

Mattioli RC, Pandey VS, Murray M, Fitzpatrick JL (2000) Immunogenetic influences on tick resistance in African cattle with particular reference to trypanotolerant N'Dama (Bos taurus) and trypanosusceptible Gobra zebu (Bos indicus) cattle. Acta Trop 75(3):263-277

McDermott JJ, Kristjanson PM, Kruska R, Reid RS, Robinson TP, Coleman P, ... Thornton PK (2002) Effects of climate, human population and socio-economic changes on tsetse-transmitted trypanosomiasis to 2050. In: The African trypanosomes. Springer, Boston, Massachusetts, USA. pp 25-38

McLeman R, Hunter L (2010) Migration in the context of vulnerability and adaptation to climate change: insights from analogues. Wiley Interdiscip Rev Clim Chang 1:450-461

Mellor P, Leake C (2000) Climatic and geographic influences on arboviral infections and vectors. Rev Sci Tech-Off Int Epizooties 19(1):41-48

New M, Hewitson B, Stephenson DB, Tsiga A, Kruger A, Manhique A, Gomez B, Coelho CAS, Masisi DN, Kululanga E, Mbambalala E, Adesina F, Saleh H, Kanyanga J, Adosi J, Bulane L, Fortunata L, Mdoka ML, Lajoie R (2006) Evidence of trends in daily climate extremes over Southern and West Africa. J Geophys Res 111:D14102. https://doi.org/10.1029/2005JD006289

Norval RAI, Sutherst RW, Kurki J, Gibson JD, Kerr JD (1988) The effect of the brown ear-tick Rhipicephalus appendiculatus on the growth of Sanga and European Breed cattle. Vet Parasitol 30(2):149-164

Nyamushamba GB, Mapiye C, Tada O, Halimani TE, Muchenje V (2017) Conservation of indigenous cattle genetic resources in Southern Africa's smallholder areas: turning threats into opportunities - a review. Asian-Australas J Anim Sci 30(5):603-621. https://doi.org/10.5713/ ajas. 16.0024

Pathiratne A, Jayasinghe RPPK (2001) Environmental influence on the occurrence of epizootic ulcerative syndrome (EUS) in freshwater fish in the Bellanwila-Attdiya wetlands, Sri Lanka. J Appl Ichthyol 17:30-40 
Rich KM, Roland-Holst D, Otte J (2014) An assessment of the ex-post socio-economic impacts of global rinderpest eradication: methodological issues and applications to rinderpest control programs in Chad and India. Food Policy 44:248-261. https://doi.org/10.1016/j. foodpol.2013.09.018

Sang R, Kioko E, Lutomiah J, Warigia M, Ochieng C, O’Guinn M, ... Hoel D (2010) Rift Valley fever virus epidemic in Kenya, 2006/2007: the entomologic investigations. Am J Trop Med Hyg 83(2_Suppl):28-37

Scarpa R, Ruto ESK, Kristjanson P, Radeny M, Drucker AG, Rege JEO (2003) Valuing indigenous cattle breeds in Kenya: an empirical comparison of stated and revealed preference value estimates. Ecol Econ 45(3):409-426. https://doi.org/10.1016/S0921-8009(03)00094-6

Siebert A (2014) Hydroclimate extremes in Africa: variability, observations and modeled projections. Geography Compass 8(6):351-367

Songe MM, Hang'ombe MB, Phiri H, Mwase M, Choongo K, van der Waal B, Kanchanakhan S, Reantaso MB, Subasinghe RP (2011) Field observations of fish species susceptible to epizootic ulcerative syndrome in the Zambezi River basin in Sesheke District, Zambia. Trop Anim Health Prod 44:179-183

Steinfeld H, Wassenaar T, Jutzi S (2006) Livestock production systems in developing countries: status, drivers, trends. Rev Sci Tech 25(2):505-516

Tanaka M, Kamiya Y, Kamiya M, Nakai Y (2007) Effect of high environmental temperatures on ascorbic acid, sulfhydryl residue and oxidized lipid concentrations in plasma of dairy cows. Anim Sci J 78(3):301-306. https://doi.org/10.1111/j.1740-0929.2007.00439.x

Thornton PK, Herrero MT, Freeman H, Okeyo Mwai A, Rege J, Jones PG, McDermott JJ (2007). Vulnerability, climate change and livestock-opportunities and challenges for the poor. International Crops Research Institute for the Semi-Arid Tropics (ICRISAT), Patancheru, Hyderabad, India

Thornton PK, van de Steeg J, Notenbaert A, Herrero M (2009) The impacts of climate change on livestock and livestock systems in developing countries: a review of what we know and what we need to know. Agric Syst 101(3):113-127

Van den Bossche P, Coetzer J (2008) Climate change and animal health in Africa. Rev Sci Tech 27(2):551-562

van Dijk J, Sargison ND, Kenyon F, Skuce PJ (2010) Climate change and infectious disease: helminthological challenges to farmed ruminants in temperate regions. Int $\mathrm{J}$ Anim Biosci 4(3):377-392. https://doi.org/10.1017/S1751731109990991

Young BA (1993) Implications of excessive heat load to the welfare of cattle in feedlots. In: Recent advances in animal nutrition, Armidale, Australia. Animal Science, Armidale, pp 45-50

Zougmoré R, Partey S, Ouédraogo M, Omitoyin B, Thomas T, Ayantunde A, ... Jalloh A (2016) Toward climate-smart agriculture in West Africa: a review of climate change impacts, adaptation strategies and policy developments for the livestock, fishery and crop production sectors. Agric Food Sec 5(1):26

Open Access This chapter is licensed under the terms of the Creative Commons Attribution 4.0 International License (http://creativecommons.org/licenses/by/4.0/), which permits use, sharing, adaptation, distribution and reproduction in any medium or format, as long as you give appropriate credit to the original author(s) and the source, provide a link to the Creative Commons license and indicate if changes were made.

The images or other third party material in this chapter are included in the chapter's Creative Commons license, unless indicated otherwise in a credit line to the material. If material is not included in the chapter's Creative Commons license and your intended use is not permitted by statutory regulation or exceeds the permitted use, you will need to obtain permission directly from the copyright holder. 